Review

\title{
Nitrogen Dynamics in Wetland Systems and Its Impact on Biodiversity
}

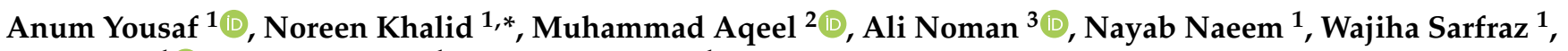 \\ Ujala Ejaz $^{1}{ }^{\mathbb{D}}$, Zonaira Qaiser ${ }^{1}$ and Arifa Khalid ${ }^{1}$ \\ 1 Department of Botany, Government College Women University, Sialkot 51310, Pakistan; \\ anumy90@yahoo.com (A.Y.); nayabnaeem09@gmail.com (N.N.); wajihaali61@yahoo.com (W.S.); \\ ujalaejaz22@gmail.com (U.E.); zamanzunaira@gmail.com (Z.Q.); Arifakhalid23@yahoo.com (A.K.) \\ 2 State Key Laboratory of Grassland Agro-Ecosystems, School of Life Sciences, Lanzhou University, \\ Lanzhou 730000, China; aqeelbutt99@gmail.com \\ 3 Department of Botany, Government College University, Faisalabad 38000, Pakistan; alinoman@gcuf.edu.pk \\ * Correspondence: noreen.khalid@gcwus.edu.pk
}

Citation: Yousaf, A.; Khalid, N.; Aqeel, M.; Noman, A.; Naeem, N.; Sarfraz, W.; Ejaz, U.; Qaiser, Z.; Khalid, A. Nitrogen Dynamics in Wetland Systems and Its Impact on Biodiversity. Nitrogen 2021, 2, 196-217. https://doi.org/10.3390/

nitrogen 2020013

Academic Editor: Wim De Vries

Received: 29 March 2021

Accepted: 27 April 2021

Published: 1 May 2021

Publisher's Note: MDPI stays neutral with regard to jurisdictional claims in published maps and institutional affiliations.

Copyright: (C) 2021 by the authors. Licensee MDPI, Basel, Switzerland. This article is an open access article distributed under the terms and conditions of the Creative Commons Attribution (CC BY) license (https:// creativecommons.org/licenses/by/ $4.0 /)$.

\begin{abstract}
Wetlands are viable sinks for nitrate and have also been identified as a source of nitrous oxide, a product of two microbially regulated processes: nitrification and denitrification. Anthropogenic expansion of nitrogen is a leading cause of the eutrophication of water bodies and may also contribute to the deterioration of the ozone layer in the stratosphere. Wetlands ameliorate the quality of water percolating through them, by retaining nutrients and sequestering carbon, and simultaneously enhancing the flora and fauna diversity of these landscapes. Among the many services these wetlands provide, they also alleviate nitrate pollution by attenuating reactive nitrogen from agricultural drainage and ensure the effective reclamation of the wastewater. The literature regarding the viability of wetlands suggests a linear relationship between the removal of nitrogen and its loading rate, thereby suggesting a potential loss of nitrogen removal capacity due to the loss of wetland area. This review discusses the nitrogen removal mechanisms in existing wetlands along with the environmental variables affecting the optimum performance and management of these wetlands, in terms of greenhouse gas retention and biodiversity. Conservation of these wetlands should be contemplated to maintain the world-wide nitrogen cycle and diminish the negative repercussions of surplus nitrogen loading.
\end{abstract}

Keywords: nitrogen; wetlands; biodiversity; conservation

\section{Introduction}

Various aquatic ecosystems have encountered a deterioration of water quality due to surplus nutrients stacking, from both point and nonpoint sources. Since 2008, sanitation concerns have imperiled the existence of about 2.5 billion individuals across the globe, through water contamination or direct contact [1]. To optimize pollutant removal, numerous natural wetlands that have recently operated as wastewater disposal sites are expeditiously being altered for agricultural and infrastructure advancement, and considering the upstream treatment of wastewaters utilizing constructed wetlands is an alternative that can be exploited to establish a sustainable supply of cleansed water. Compared to conventional mechanical treatment systems, constructed wetlands productively incorporate the treatment of wastewater, as well as resource enhancement, at a cost-effective rate (60-95\%).

Point source pollution alludes to pollutants that come from a definite, traceable source. Whereas, nonpoint source pollutants may appear in untraceable runoff from agriculture, mining, oil, and gas operations, and are laborious to evaluate as they originate from diverse landscapes and various diffuse sources. Pollutants deriving from agricultural runoff introduce dissolved organic carbon, nitrogen, phosphorus, pesticides, salts, sediments, and trace elements into the ecosystem [2]. It has long been established that an abundance of 
nitrogen, along with phosphorous, is responsible for the eutrophication of coastal waters, estuaries, and inland waters [3,4]. Nitrogen is applied to arable land as inorganic fertilizers, manure, and urea, however, in tile drainage nitrate- $\mathrm{N}$ is the major nitrogen form, whereas all other forms are transformed into nitrate- $\mathrm{N}$ via hydrolysis and nitrification.

Powlson and Addiscott [5] indicated urea as the most frequently used nitrogen fertilizer. After application, urea is hydrolyzed to ammonia-N within a few days, and if not absorbed by plants, ammonia- $\mathrm{N}$ is nitrified to nitrate- $\mathrm{N}$ within a month. Nitrate is a chemically inert form of nitrogen and can effortlessly be leached off from the soil profile [6]. Tillage practices have been proclaimed to affect nitrate leaching to a great magnitude. This nitrate leaching effect is distinctively variable, and the consequences are the highest when tillage takes place just before a high-water recharge. Wetlands act as biofilters that help eliminate particulate matter, as sinks collecting nutrients, and also as transformers turning these nutrients into various gaseous forms of nitrogen [7]. The ability of natural wetlands to retain nitrogen was first reported in the 1970s [8]. Acreman [9] evaluated the accessible results from 54 natural wetlands in Africa, Asia, Australia, Europe, and North America and estimated that $80 \%$ of these wetlands removed an average of $67 \%$ nitrogen. The significant processes accountable for retaining nitrogen are denitrification, nitrogen uptake by plants followed by nitrogen amassing in the plant biomass, sedimentation, and volatilization.

Over the 20th century, wetlands have been broadly viewed as biological filters, providing security to water resources, such as estuaries, groundwater, lakes, and streams. Even though natural wetlands have served as ecological buffers, the research and development of wetland treatment technology is a fairly recent phenomenon, as very little information has been obtained about their biological principles and underlying ecological functioning. Nevertheless, the expanded demands on wastewater treatment effectiveness and the rising cost of traditional treatment systems correspondingly required a better comprehension of wetland treatment operations. Hence, in 1974 the emergence of the first operative horizontal subsurface flow constructed wetland led to the commencement of studies of the viability of employing wetlands for wastewater treatment during the 1950s in Germany. This review highlights the potential and basic mechanism of wetland systems to reduce nitrogen loadings to water bodies, and their impact on species diversity. The significant variables that are supposed to alter the proper functioning and effectiveness of wetlands are also assessed in order to identify the decisive practices for nitrogen management.

\section{Method}

The search for literature was carried out on the internet and relevant electronic databases. No specific document type, duration, or language restraints were enforced. All the retrieved documents were screened by one author according to abstract and title standard. The subsets of forty documents were further screened by other authors to monitor the coherence and compliance of the screening, according to the accepted inclusion and exclusion criteria. After screening, the remaining relevant data were analytically assessed and assigned to three quality grades, the data were derived from two of them.

\section{What Are Wetlands?}

Cowardin et al. [10] put forth a systematic definition of wetlands as "terrains where the nature of soil development and the communities of animals and plants thriving in it and on its surface are determined by the saturation level of water". The USEPA [11] stated wetlands as "those lands that are immersed with ground or surface water at an adequate recurrence and span to support prevalent vegetation generally suitable to live in saturated soil environment under normal circumstances. Wetlands typically include bogs, marshes, swamps, and related areas." Wetlands are occasionally located in brackish, freshwater, and saline environments, within abandoned ditches, estuaries, lakes, and rivers, on slopes where water erupts from the ground as a seep or spring, stream channels, and other similar areas. 
Wetlands are the territories where the water table is at, or near, the ground surface and gravel and rocks are inundated in water sporadically or the whole growing season. Water tolerant plant species, known as hydrophytes, are accustomed to flourish in the hydric region of wetlands. Naturally, wetlands occur in our environment, but they can also be established to prompt the functions and operations of natural wetlands. Natural wetlands are defined as transitional regions that occur amid aquatic and terrestrial ecosystems [12].

\subsection{Classification of Wetlands}

Wetlands have been classified as water reservoirs that are perennial and are constructed by underground water sources or potential rainfall [13]. Therefore, wetlands are boggy lands filled with stagnant or flowing fresh or saline water representing arable lands, boggy areas, flood plains, lagoons, plains, ponds, and water storage areas. Natural wetlands consist of bogs, lakes, marshes, rivers, streams, and swamps; whereas, anthropogenic wetlands comprise canals, fish farms, paddy fields, ponds, etc. These wetlands blanket approximately $6 \%$ of the earth's surface area, and exist in almost every state, from tropical regions to tundra [14].

According to Kadlec and Knight [15], the hydrologic conditions of wetlands are a significant factor that determine the biodiversity, geomorphology, habitat quality, and water quality. The EPA categorized wetlands into four common types in the US, i.e., bogs, fens, marshes, and swamps [16]. The aforementioned types are described as:

Marshes are frequently saturated with water, providing optimum conditions for the growth of herbaceous plants. Based on their location, they are further categorized into tidal marshes that exist near coastlines and are affected by tides and seldom by freshwater from rivers and runoff. Meanwhile, herbaceous species dominate the non-tidal marshes situated in poorly drained depressions and shallow water regions near the edges of various lakes and rivers.

Swamps contain stagnant water, and are covered with shrubs and woody trees. They occur in both freshwater and saltwater floodplains and are distinguished for having wet soil conditions during the growing season and stagnant water at specific times annually. Depending upon the vegetation type, they are termed as forested, mangrove, and shrub. Forested swamps receive freshwater from neighboring streams and rivers. Mangrove swamps are found along with the coastal areas and are identified for salt-tolerant shrubs and trees that grow in brackish to saline waters. Whereas, shrub swamps are related to forested swamps but are dominated by shrubby plants, such as buttonbush and swamp rose.

Bogs accommodate freshwater blanketed with spongy peat deposits and sphagnum moss, along with growing shrubs and evergreen trees. They hold acidic water with low nutrient levels and therefore are not suited for proper plant growth. Bogs are classified as northern bogs and pocosins, based on their location.

Fens are peat composing wetlands that are periodically fed with groundwater. They have high a nutrient content and are less acidic than bogs. Larger communities of animals and plants, such as grasses, sedges, and wildflowers, dominate these wetlands.

\subsection{Functions of Wetlands}

Wetlands are valuable for supporting habitats for both aquatic and terrestrial animals and plants, as well as providing nests for migrating bird species. They absorb and slow down floodwaters and hence keep flooding in check. They are also utilized for recreation purposes, such as bird watching, canoeing, fishing, and hiking. Wetland systems are employed in wastewater treatment, as they can absorb nutrients, pollutants, and sediments. Wetlands can be established to provide the above-mentioned benefits; for example, constructed aquaculture wetlands, constructed flood control wetlands, constructed habitat wetlands, and constructed wastewater treatment wetlands [12]. Constructed wetlands are manufactured for optimum performance for a specific operation, therefore, these wetlands are much more dynamic than natural wetlands. 
Wetlands also sequester carbon and contain the maximum $C$ density among various terrestrial ecosystems due to elevated organic matter deposition and decreased rates of decomposition. Even though wetlands emit about 40 percent of the total global methane, soil C in wetland systems is still acknowledged as the substantial constituent of global $\mathrm{C}$ budgets. It is noted that terrestrial environments, along with wetlands, can sequester

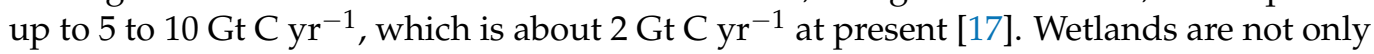
garnering attention for attenuating contaminants and conserving biodiversity, but are also protected for their increased potential to sequester $\mathrm{C}$ beyond the present levels.

\section{Constructed Wetlands and Nitrogen Cycling}

Constructed wetlands, also termed reedbeds, are engineered systems particularly designed to galvanize a natural wetland for the treatment of wastewater. Constructed wetland technology was founded by two German scientists, namely Dr. Käthe Seidel and Dr. Reinhold Kickuth. The research in this field gained momentum after the second international conference on constructed wetlands in 1990, at Cambridge, UK.

Among different nitrogenous species, dissolved inorganic nitrogen groups such as ammonia, ammonium, nitrite, or nitrate greatly influence the aquatic systems, as they are readily available for uptake by aquatic microorganisms rather than other particulate organic nitrogen species. Specific treatment operations, like combined nitrification-denitrification, and sedimentation specifically at the sediment-water and water-plant interfaces, are exploited to discard various nitrogenous species. Optimization of nitrogen attenuation is a critical subject, as nitrogen-rich discharges into recipient aquatic systems are the major cause of ecosystem damage. Thus far, activated sludges along with biofilm processes are being used for biological nitrogen attenuation. These configurations have been established for biological wastewater treatment to attain desired effluent standards.

Biofilm processes are utilized for biological carbon, nitrogen, and phosphorous removal and are expensive, especially when used in small and medium communities. Contrarily, a wetland is cost-effective, as it employs natural treatment routes that consume less electricity and labor and also have lower construction and maintenance expenses for chemicals, fuels, and plant operation. Furthermore, constructed wetlands are potent for nitrogen removal; however, on account of the observed inadequacy of nitrogen transformation and removal mechanisms, they have proven inconsistent.

Constructed wetlands can minimize biological oxygen demand, and coliform bacteria, nitrogen, phosphorous, and suspended solid concentrations by up to 98 percent. If these wetlands are constructed on an appropriate topography, they can treat waste from small communities and rural sites, because of their simple design, small energy input, and scalability.

\subsection{Limitations}

Constructed wetlands are comparatively more tolerant to fluctuating pollutant load and have a less restricted design life period than a wastewater treatment plant. However, they also show some limitations, as their performance is highly impacted by usage and climate conditions. Constructed wetlands often require a large land area, and a long duration for vegetation growth to attain effective treatment capacity. Moreover, the large ground area holding stagnant water can also become a breeding abode for mosquitoes and various insect species. Moreover, steep topography and high-water table localities affect the construction of these wetlands.

\subsection{Types}

Constructed wetlands are designed such in a way that the lining does not affect the groundwater, and the duration for which these wetlands retain the water is defined as the hydraulic residence time. Hydraulic loading rate, i.e., loading on a water volume per unit area basis, is a significant factor in wetland construction. Precipitation, storage, and wastewater are the wetland's inputs, while evapotranspiration, effluent removal, and 
transpiration are lost from wetlands. Based on hydraulic water flow, constructed wetlands have two main types:

\subsubsection{Surface Flow System}

In surface flow regimes, the water depth varies between 4 to 6 inches and they accommodate dense vegetation. For wastewater treatment, continuous-marsh and marshpond-marsh configurations of surface flow constructed wetlands are given preference in the United States. The base of these wetlands is slightly permeable, as it allows water exfiltration, passing above the supporting medium, chiefly between the plants' stems and surface debris. Sunlight enters through a water basin into the system, which promotes active photosynthesis, as well as the growth of algae. Surface flow wetlands are costeffective, but they show comparatively lower contaminant attenuation efficacy than SSF wetlands. A recent attempt has been made to boost nitrogen attenuation efficacy by establishing an open-water zone without any vegetation.

\subsubsection{Sub-Surface Flow System}

Constructed wetland systems are widely popular globally for biological wastewater treatment. However, variable climatic circumstances, particularly in frigid environments, often obstructs their efficient performance, as these climates influence the microbial activity and metabolic rate of plants. To overcome this limitation, subsurface flow regimes are preferred in temperate regions, such as in Africa and Europe.

SSF systems broadly comprise a ditch that contains media to aid plant growth. The presence of a media layer consisting of rock and gravel above the water level increases its waste removal efficiency, as the rocks used in this media make it perforated, which enables the microbes to freely interact with wastewater. SSF wetland systems are chiefly known for the active removal of pathogens, along with BOD, COD, nitrogen, phosphorous, and SS metals.

At present, new and advanced wetland systems are being developed by hybridizing characteristics of various wetland types, so that the highest potential to eliminate pollutants can be achieved. For instance, by prompting tidal flow, or equipping the wetland with a modified flow-shift module to increase organic matter decomposition with the help of microorganisms.

\subsubsection{Partially Saturated Vertical Flow Constructed Wetland: A Hybrid System}

The technique of partially saturated vertically constructed wetlands is an innovative method for upgrading the nitrogen attenuation from wastewater and has mainly been employed in Europe. Partially saturated vertically constructed wetlands are verified as more dynamic than free-flow vertically constructed wetlands, due to an increased nitrogen removal rate of about 20 to 30 percent. The system is known to attenuate the same number of contaminants, while occupying less space than is achieved in both vertical and horizontal subsurface flow constructed wetlands combined. Moreover, the presence of emergent species, such as Canna hybrids and Zantedeschia aethiopica, in partially saturated vertically constructed wetlands increases the percentage of dissolved oxygen in the wetland system, whilst assisting with the removal of ammonium and phosphorus compounds, and furthermore increases the aesthetic value of the wetland system. Recently, lignocellulosic residues have been employed in partially saturated vertical wetlands to boost total nitrogen removal.

\section{Nitrogen Dynamics in Wetland Systems}

\subsection{Mineralization}

Mineralization, also termed ammonification, is the first step in the nitrogen attenuation process, in which the organic $\mathrm{N}$ is mineralized to ammonia by various microbes that derive their energy from organic carbon. The ammonification process is either aerobic or anaerobic, i.e., facilitated by aerobic bacteria, facultatively anaerobic bacteria, or obligate anaerobic 
bacteria (Figure 1). Larger organic nitrogenous molecules such as amino acids and proteins are transformed into smaller dissolved and particulate organic molecules and eventually to ammonium, which is either taken up by plants or soil microorganisms or gets dissolved in soil or water.

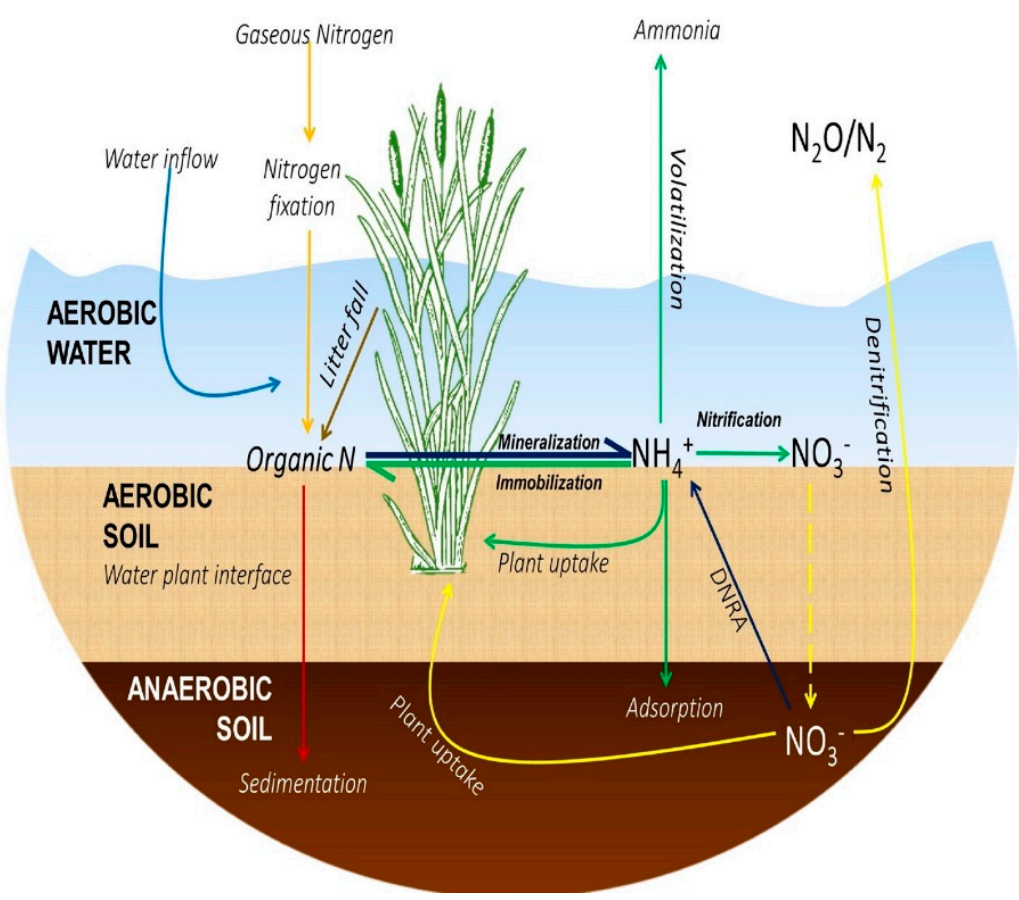

Figure 1. Illustration of the potential pathway for nitrogen transformation in wetlands.

Certain geochemical conditions, i.e., the available nutrients in the wetland system, $\mathrm{pH}$, soil structure, soil texture, temperature, and the carbon to nitrogen ratio of the residue impact the rate of mineralization. In saturated soils, $\mathrm{pH}$ is buffered around 6.5 to 8.5 (neutral), but in well-drained soils, the production of protons and nitrate accumulation acidifies the soil. Temperature particularly influences the aerobic ammonification process, but the presence of facultative bacteria enables efficient treatment over the temperature range from 5 to $20^{\circ} \mathrm{C}$. Since these oxidation processes are catalyzed by a diverse group of microorganisms, they do not limit the nitrogen attenuation process under various geochemical circumstances [15]. Hence, ammonification is never a rate-limiting process, and is not reviewed in-depth for designing a typical wetland, but is considered to gauge the efficacy of the constructed wetland.

\subsection{Nitrification}

The biological oxidation of ammonia to nitrite (nitritation) by ammonium oxidizers or nitrate (nitratation) by nitrite oxidizers under aerobic conditions is a decisive chemoautotrophic reaction in the nitrogen cycle and for amelioration of water quality of the aquatic ecosystem. Nitratation is an exergonic process that yields plentiful energy for the synthesis of new cells. To achieve effective treatment, nitrification is optimized by the distinctive groups of bacteria belonging to family Nitrobacteriaceae that work in a series to oxidize inorganic nitrogen. Primarily, the oxidation of ammonium to nitrate is catalyzed by chemolithotrophic ammonium oxidizers of the genera, Nitrosococcus, Nitrosolobus, Nitrosomonas, Nitrosopira, and Nitrosovibrio. Then, facultative chemolithotrophs, including Nitrobacter, Nitrococcus, Nitrocystis, Nitrospina, and Nitrospira, regulate the oxidation of nitrite into nitrate. Generally, these bacteria efficiently lower ammonium and nitrite concentrations but are highly sensitive and grow at a very slow pace. These attributes are due to specific substrates used for metabolism, so analysis of processes for carbon fixation, 
electron donation, and energy production will facilitate ways to improve their habitats for growth.

Although nitrification is an anoxic process, research has shown that ammonia oxidizers are capable of oxidizing ammonia in anoxic environments. Apart from actinomycetes and planctomycetes, certain algae and fungi are also capable of nitrification. Nitrification takes place in root zones, the soil-water interface, and specific aerobic zones of the water column, where the required oxygen is provided by diffusion from the atmosphere or exposure of macrophyte roots. Investigations have also revealed that dissolved oxygen levels below 1 to $2 \mathrm{mg} / \mathrm{L}$ in water decrease nitrification to a greater extent. It was reported that in pilot-scale downflow wetlands, about $73 \%$ to $93 \% \mathrm{NH}_{4}+-\mathrm{N}$ was removed with varying filter media, and the existence of plants, i.e., P. australis, was not at all substantial [18]. For the improvement of nitrification, strategies involving aeration, effluent recirculation, and rapid low-volume dosing showed that enhanced oxygen transfer resulted in improved nitrification, along with 40 to 90 percent attenuation of ammonium [19].

\subsection{Denitrification}

Denitrification is an enzymatic anoxic reduction reaction, in which chemoorganotrophic bacteria, lithoautotrophic bacteria, or phototrophic bacteria reduce nitrite and nitrate to molecular or gaseous nitrogen. Tiedje [20] stated that facultative anaerobic bacteria, such as Alcaligenes, Bacillus, Flavobacterium, Paracoccus, and Pseudomonas, use nitrate irreversibly in the electron transport chain as a terminal electron acceptor. The denitrification process is favored by high carbon content and low redox potential. In situ production of ammonium ion from mineralization and nitrate ion supply through diffusion from aquatic bodies drives the denitrification process.

Woodward et al. [21] reported the microbe-mediated processes of denitrification and biological uptake as the most significant sinks for nitrate removal. Upon decomposition of biomass, the nitrogen assimilated by microorganisms and plants is diffused back into the system. Lin et al. [22] indicated that 4 to 11 percent of nitrogen was attenuated by wetland vegetation, while the remaining 89 to 96 percent removal was due to the process of denitrification. Mayo and Bigambo [23] investigated the nitrogen transformation mechanisms in wetland systems and disclosed that a maximum removal of nitrogen ( 29.9 percent) was contributed by denitrification, followed by plant uptake (10.2 percent) and sedimentation (8.2 percent). Therefore, quantifying denitrification potential is crucial. The typical techniques that are used for this quantification include: the acetylene inhibition technique, mass balance, membrane inlet mass spectrometry, and $\mathrm{N}$ tracers. The magnitude of denitrification can also be estimated by the radical $\mathrm{N}_{2} \mathrm{O}$ accumulation, known as denitrification enzyme assay (DEA).

\subsubsection{Measurement of Denitrification}

As the calibration of the product of denitrification, i.e., nitrogen against atmospheric nitrogen $(78 \%)$, is challenging, therefore, measuring denitrification is arduous as well. Besides, the calibration methods also alter the physical environment, including the availability of oxygen and moisture content, as well as varying the soil structure and concentration of substrate. Furthermore, soils are exceptionally heterogeneous, so scaling assays executed on limited soil samples to the entire ecosystem is a difficult task.

\subsubsection{Acetylene Inhibition Method}

The acetylene inhibition method depends on the linear accumulation of nitrous oxide emitted during soil incubation, to which acetylene is added to restrict bacterial activity to transform nitrous oxide into gaseous nitrogen [24]. During the process of denitrification, nitrous oxide is accumulated as an intermediate product, which can be calculated accurately by sensitive nitrous oxide detectors, as the atmospheric content of $\mathrm{N}_{2} \mathrm{O}$ is extremely low.

The acetylene present in this technique is far from calculating an actual rate of denitrification, because the soil samples are homogenized and are placed under optimal anaerobic 
circumstances that may not occur in nature. Moreover, it also blocks the production of nitrate via nitrification, which may lead to an aberration in the denitrification process as the substrate source is removed. Therefore, at a very low concentration of nitrate, this could become a serious problem.

On the other hand, the process can be proved valuable, as various samples can be run simultaneously across different sites, the carbon and nitrogen limitation can be overcome, and under controlled laboratory conditions of carbon and nitrogen, a comparison of limiting factors of the denitrification process can be made in various sites.

\subsection{Volatilization}

In wastewater treatment wetlands, if the $\mathrm{pH}$ is less than 7.5, loss of ammonia via volatilization is insignificant compared to nitrification and denitrification. However, if $\mathrm{pH}$ is more than 7.5, the concentration of the unionized form of ammonia gets relatively high, and $\mathrm{NH}_{3}$ is discharged into the atmosphere. The volatilization process is not considered as an important factor for nitrogen cycling in many wetland systems, but in poorly buffered waters it can lead to significant nitrogen losses because of the rise in $\mathrm{pH}$ due to the increased photosynthetic activity of various algae, as well as free-floating and submerged macrophytes.

\subsection{Sedimentation}

Sedimentation attenuates most of the particulate organic nitrogen in many constructed wetlands, which may adhere to the stem of plants or may settle on the floor of wetlands. Various microbes and plants utilize the decomposed matter, like TN, TP, and low molecular weight organic compounds. In wastewater treatment, for the amelioration of nitrogen and phosphorous, an improved sedimentation technique has recently been established that uses magnesium-ammonium-phosphate as a precipitation reagent and has the potential to be implemented in constructed wetlands.

\subsection{Plant Uptake and Matrix Adsorption}

In a wetland system, the uptake by plants and matrix adsorption is also involved in the regulation of nitrogen. However, the wetland is supposed to have a finite storage capacity, and the nitrogen stored can undergo remineralization or desorption, hence this mechanism provides a temporary solution. In plants, nutrients are very much needed for growth and reproduction, and are fundamentally taken up by roots in macrophytes. Plants net productivity and nutrient accumulation in plant tissues tend to limit the potential of these macrophytes to absorb nutrients. Thus, a moderate volume of nutrients can be discarded from the wetland system via plant biomass harvesting based on the macrophyte consumed. In tropical wetlands, the quantity of nutrients attenuated through plant uptake and storage is about 25 to 89 percent, contrary to the insignificant amount evacuated by plant harvesting. Harvesting is chiefly significant for the removal of phosphorous, rather than nitrogen, because it is non-volatile. In reduced form, due to variations in ammoniumnitrogen content of the water, sequential loading and unloading of the sorption sites start to occur, and as a result, the wetland systems charged with wastewater remove $\mathrm{NH}_{4}-\mathrm{N}$ via adsorption mechanisms.

\section{Role of Faunal Communities in Wetlands}

Aquatic invertebrates play a crucial role in the food chains of freshwater wetlands by creating a linkage between the detrital supply of wetlands and higher-level consumers. Aquatic macrophytes add detritus into the systems, which is colonized by microorganisms as soon as it infiltrates the water column. These litter particles, along with their related microbes, are then grazed upon by shredders and grazers, such as snails and amphipods. These scrappers actually reduce the size of litter particles, so they become available for various consumers. According to Nelson and Kadlec [25], the transportation of these fine litter particles is the most significant variable that influences invertebrate assemblage in wetlands. Filter feeders collect minute particles from the water stream, whereas the 
fine particulate organic matter descended on the surface of substrate is accumulated by collectors. The Chironomidae is considered one of the most dominant invertebrate class of wetland systems, and represents both collectors and scrappers. Moreover, vertebrates including muskrats adversely affect the vegetation of wetlands, contrary to the smaller feeding invertebrate groups that mainly depend upon algal communities. These invertebrates are preyed upon by vertebrate consumers as food, for instance, waterfowl feeding on invertebrates and breeding ducks feeding on snails to meet their amino acid and high calcium requirements for gonadal development and egg-shell formation, respectively [26].

The composition of invertebrate communities of various wetland types exhibit rich species diversity and productivity. The peatlands of arctic and boreal zones of Asia, Europe, and North America provide a habitat for large communities of invertebrates. Usually, small insects of the order Lepidoptera represent the Northern peatlands, whereas ant species of the family Formicidae are particularly endemic to bog mats. The coastal wetlands of the Great Lakes of North America also support a vast diversity of benthic invertebrates, with more than 500 species likely to inhabit them. Alternatively, the amphipods of the genera Crangonyx, Gammarus, and Hyallela, along with the Isopods of the genera Lirceus and Caecidotea, are the most conspicuous inhabitants of the floodplain wetlands. Although, wetland fauna communities are diverse and productive, they still face severe threats posed by abiotic environments in the wetlands.

\section{Impact of Vegetation on Nitrification and Denitrification}

Nutrient absorption and oxygen input through plant roots are hypersensitive to air and water content balance in the soil [27]. High air-content in the root area favors the growth of aerobic microorganisms, like Nitrobacter and Nitrosomonas, which transform ammonium into nitrate ions for plant uptake, while, low air-content benefits the growth of facultative microbes involved in denitrification, which transform nitrate into nitrite or gaseous nitrogen. Studies on constructed wetlands have claimed that in up-flow wetlands, nitrogen uptake by plants accounts for the bulk ammonium removal [28]. Nevertheless, it has been reported that planted wetlands remove larger volumes of nitrate than those of unplanted wetlands [22].

The vegetation impacts both nitrifying and denitrifying bacteria in various ways, as organic carbon is generally provided by the vegetation in the wetlands. Heterotrophic bacteria, mainly denitrifying bacteria, utilize organic matter as a source of carbon and energy, which is associated with the lignin and nitrogen composition in the plants [29]. The vegetation effect on denitrification also depends on the plant litter quality and quantity. Furthermore, free-floating, as well as submerged, plants usually have lower lignin to nitrogen ratio than that of emergent plants, hence the organic matter obtained from the submersed plant species is more readily available for decay, and eventually for denitrification, than the organic matter obtained from emergent plant species [30]. Therefore, for emergent macrophytes, the net primary production is higher and their organic matter lasts a for longer period of decomposition than submersed plants. Besides, the seasonal pattern of debris inflation may also significantly influence the accessibility of organic matter, as well as the redox circumstances in the sediments.

Investigations have revealed that dead leaves remain attached to the stem axis of $P$. australis till late fall and only afterward become detached and drop to their littoral stand, where they become available to the microbes. In another study on G. maxima, it was disclosed that the loose litter quantity not linked to dead shoots rose to a maximum in November to March, and later reduced to a minimum at a faster pace in May. In addition, the amount of debris in the sediment layers may inhibit the diffusion of oxygen to the lower layers of sediment, which favors the denitrification process but is unfavorable for nitrifying bacteria. Moreover, plant tissues yield a large surface area for the growth of microorganisms. In the aquatic environment, attached bacteria tends to be more active and abundant than free-living microbes [31]. These microbes attached to submersed solid surfaces, like sediment and macrophytes, form biofilms. For surfaces in the aquatic systems 
to which bacteria tend to adhere, having a higher concentration of oxygen and ammonium would encourage nitrification. However, it has not yet been established whether or not some surface structures in wetland systems are more suitable than others for various nitrogen transformations.

Eriksson and Andersson [32] reported that the litter of various emergent macrophytes differed in quality with varying habitats for nitrifiers, and that they exhibited more extreme ammonium and nitrate oxidation in the litter of Carex rostrata and Scirpus sylvaticus than in the litter of Equisetum fluviatile and Typha latifolia. Sediments are the most common sites known for denitrification, but recent investigations have revealed that the denitrification process in periphytic associations on submerged macrophytes can contribute considerably to overall denitrification in a wetland system. Likewise, submersed macrophytes release oxygen via photosynthesis into the water, whilst in emergent macrophytes transportation of oxygen occurs from stem aerenchyma to the rhizome and root, following its diffusion to the sediment and water [33]. Thus, living and dead vegetation in the wetland system can impact the microbial activity of both nitrifying and denitrifying bacteria in various ways. However, the vegetation type within a wetland system that best supports nitrification and denitrification is yet to be established.

Recently, the use of ornamental plants for wastewater treatment has been established in 21 countries of the world, and favors oxygenation and growth of aerobic bacteria populations. Emergent plants are most commonly employed as ornamentals in constructed wetlands, including Acorus gramineus, Agapanthus africanus, Canna indica, Canna generalis, Heliconia sp., Iris pseudacorus, Strelitzia reginae, Typha angustifolia, and Zantedeschia aethiopica [34]. Zhang et al. [34] noted that the presence of ornamental species was significant for the attenuation of total nitrogen (TN) in wetlands. Chiefly, Acorus gramineus and Iris pseudacorus displayed the stronger total nitrogen (TN) reduction capacity among other ornamental species, such as Acorus calamus, Alilsma orientale, Lythrum salicaria and Reineckra carnea. Zurita et al. [35] examined five ornamentals, namely Anthurium andreanum, Canna hybrids, Hemerocallis dumortieri, Strelitzia reginae, and Zantedeschia aethiopica in laboratoryscale SSF constructed wetlands and observed the quality standard of the effluents and better development of the plants.

\section{Oxygen Transport}

Green et al. [36] observed a maximum aeration capacity for a nitrification potential of 65.7 milligrams per liter in a vertical downflow wetland, where oxygen was transported in the system by a siphon effect harvested from flooding and drainage in the soil column. Lahav et al. [37] also examined the oxygen transfer efficiency of a vertical downflow system and stated that it is directly proportional to a particular surface area but is inversely related to the hydraulic loading rate. Sun and Austin noted that vertical flow systems regulated oxygen saturation throughout the columns during the time of nitrification and total nitrogen discharge [38]. Whereas, in up-flow wetland systems, oxygen transport has not been reported. It is noted that the oxygen stoichiometric demand for nitrification is about $1.86 \mathrm{~mol} \mathrm{O}_{2} / \mathrm{mol} \mathrm{NH}_{4}+-\mathrm{N}$, which may enter the system through the advection generated via soil-gas-pressure-induced flow, diffusion of gas from the surface, effusion from macrophytes roots, and wastewater.

\section{Other Ecological Factors Influencing Nitrogen Removal Efficiency}

In constructed wetlands, certain pollutants are degraded employing various biological and physicochemical processes, so diverse ecological variables can impact the removal of nitrogen in many ways. The principle factors are climate, features of microbial communities, distribution of wastewater, hydraulic residence time, temperature, and vegetation density and type. Therefore, to improve the efficiency of nitrogen removal and ameliorate water quality in wetland systems, variables that stimulate the growth of macrophytes and certain microbes, including the concentration of dissolved oxygen, harvesting of the hydrophytes, hydraulic residence time (HRT), optimization of $\mathrm{pH}$ and temperature, as well 
as planting depth, must be scrutinized. Two major variables are temperature and hydraulic residence time.

\subsection{Temperature}

Temperature is a fundamental factor that is significant for the denitrification potential and the proper activity of nitrifying bacteria in treatment wetlands. In constructed wetland systems, both microbial activity and rate of diffusion of oxygen are influenced by temperature, and the nitrogen is removed most efficiently at 20 to $25^{\circ} \mathrm{C}$. At below $15{ }^{\circ} \mathrm{C}$ or a $30{ }^{\circ} \mathrm{C}$ temperature, the activity of microbes associated with nitrification and denitrification reduces significantly. Moreover, almost all microbial communities related to nitrogen attenuation function properly at above $15^{\circ} \mathrm{C}$.

Several investigations have reported that the performance of denitrifying bacteria in the sediments of constructed wetlands is more potent in spring and summer months than in the fall and winter. Additionally, the nitrate removal rate is highest in summer, whereas denitrification generally ceases at temperatures lower than $5^{\circ} \mathrm{C}$. The optimum temperature reported for nitrification in soils is about 30 to $40^{\circ} \mathrm{C}$, while for ammonification the optimum temperature range is 40 to $60{ }^{\circ} \mathrm{C}$. While, the optimum $\mathrm{pH}$ for ammonification ranges from 6.5 to 8.5 . However, at low temperatures, nitrification is inadequate to prevent a net rise in the concentration of ammonia due to ammonification.

\subsection{Hydraulic Residence Time}

HRT also plays a decisive role in nitrogen removal efficiency. Huang et al. [39] demonstrated that by increasing wastewater residence time, the concentration of ammonium and total Kjeldahl nitrogen reduced remarkably in treated effluents. In many wetlands, a comparatively longer HRT is required for nitrogen attenuation than BOD and COD removal. Nitrogen removal efficiency also differs with flow circumstances and residence time. Akratos and Tshihrintzis observed an optimum 8-day HRT at a temperature above $15^{\circ} \mathrm{C}$ in an SSF wetland system.

\subsection{Vegetation Type}

To enhance the treatment performance, as well as to optimize the layout of constructed wetlands, it is necessary to discern the competence of diverse plant species, the specific traits of microbes, and the association between biogenic materials and specific components in contaminants. Helophytes play a vital role in wastewater treatment systems, as they can withstand severe ecological circumstances because of their growth physiology. Wissing [40] stated three basic systems of natural wetlands, namely an aquaculture system, a hydrobotanical system, and lastly a soil system that provides nutrients to plants and microbial films. In a horizontal flow system, these helophytes are involved in oxygen transportation to the soil.

Macrophytes that are adjusted to anoxic rhizospheres can withdraw oxygen from the atmosphere, which can subsequently be used for respiration. An oxidative protective film is also developed on the root surface, mainly due to oxygen release. Many studies have reported that the redox potential of the plant rhizosphere has a crucial effect on the rate of oxygen release through helophyte roots. Furthermore, microphytes also significantly treat wastewater via nutrient uptake and surface bed stabilization.

In constructed wetlands, water-tolerant macrophytes, e.g., bulrush (Scirpus spp.), cattail (Typha spp.), and reed (Phragmites australis), have a greater impact on nitrogen attenuation than the removal of organic material. Nutrient removal through emergent plants is carried out by two main mechanisms: absorption by the plant, and microbial activity near the rhizome. Reed dead matter concentrated in the soils increases the BOD of freshwater in treatment systems and is also a cause of eutrophication. Therefore, to control the $\mathrm{CO}_{2}$ gas influx and re-discharge of nutrients into the recipient water, the plants' harvesting must be supervised properly and at an appropriate time. 
Numerous operational variables, including uneven bed surfaces, water depth, and water level, can be utilized to manage colonization and vegetation populations. Hammer [41] identified that an ideal plant species in constructed wetlands shows these salient features: an autogenous species suited for the regional climate and soil, fast growth, easy production, being a habitat to wildlife, being perennial, and pollutant resistance. Breen observed that regular plant harvesting may improve the potential for nutrient removal. However, Kadlec and Knight [15] reported that although plant uptake is an important route for removing nitrogen from wetlands, efficient plant harvesting from treatment systems has not been proven favorable in extensive operations, because the process is expensive and less sustainable. Thus, more research must be done on the optimal volume and appropriate time of plant harvesting to boost treatment performance.

\section{Wetland Nutrient Retention}

The statistics of 37 wetlands from all around the world were reviewed, and it was noted that wetlands impact the nutrient loadings by increasing the loading of soluble nitrogen species, and thereby potentially boost aquatic eutrophication (Table 1). It was also reported that swamps and marshes were slightly more effective at nutrient reduction than riparian zones. These attributes must be considered when operating wetlands for nutrient reduction, as their astute use will be a significant strategy to meet water framework directive requirements for aquatic entities.

Table 1. List of references recording nutrient retention in wetlands. $\mathrm{N}=$ several $\mathrm{N}$ species, $\mathrm{NO}_{2}=$ nitrite, $\mathrm{NO}_{3}=$ nitrate, $\mathrm{NH}_{4}=$ ammonium, $\mathrm{P}=$ several $\mathrm{P}$ species, $\mathrm{TN}=$ total or Kjeldahl nitrogen, $\mathrm{TP}=$ total phosphorous, and TPN $=$ total particulate nitrogen.

\begin{tabular}{|c|c|c|c|c|c|c|}
\hline Ref No. & Year & Author(s) & Wetland Name & Wetland Type & $\begin{array}{l}\text { Nutrient } \\
\text { Retention }\end{array}$ & Country \\
\hline [42] & 2004 & Axler et al. & Unknown & Constructed & $\mathrm{N}, \mathrm{TN}$ & $\begin{array}{c}\text { Duloth, } \\
\text { Minnesota }\end{array}$ \\
\hline [43] & 1995 & Baker and Maltby & $\begin{array}{l}\text { Kismeldon } \\
\text { Meadows and } \\
\text { Bradford Mill }\end{array}$ & Riparian & $\mathrm{NO}_{3}, \mathrm{NO}_{4}$ & UK \\
\hline [44] & 1998 & Bridgham et al. & Unknown & Stream & $\mathrm{N}, \mathrm{P}$ & Minnesota \\
\hline [45] & 1998 & Burt et al. & $\begin{array}{l}\text { R.Leach } \\
\text { floodplain }\end{array}$ & Floodplain & $\mathrm{NO}_{3}$ & UK \\
\hline [46] & 2002 & Busse and Gunkel & Unknown & $\begin{array}{l}\text { Riparian alder } \\
\text { fen }\end{array}$ & $\mathrm{N}, \mathrm{P}$ & $\begin{array}{l}\text { Berlin, } \\
\text { Germany }\end{array}$ \\
\hline$[47]$ & 1998 & Chauvelon & Rhone river delta & Riverin delta & $\mathrm{N}, \mathrm{P}$ & UK \\
\hline$[48]$ & 1990 & Cooper & $\begin{array}{c}\text { Scotsman Valley, } \\
\text { NZ }\end{array}$ & Riparian & $\mathrm{NO}_{3}$ & New Zealand \\
\hline$[49]$ & 1996 & Daniel and Gilliam & Cecil soil area & Riparian & $\mathrm{N}, \mathrm{P}$ & USA \\
\hline [50] & 1994 & Dorge & Rabis Baek & Peatland & $\mathrm{NO}_{3}$ & Denmark \\
\hline [51] & 1993 & Fleischer et al. & Unknown & Ponds & $\mathrm{N}$ & Sweden \\
\hline$[52]$ & 1983 & Gersberg et al. & Unknown & Constructed & $\mathrm{N}, \mathrm{P}$ & Santhe, CA \\
\hline$[53]$ & 1993 & Green and Upton & Unknown & Constructed & $\mathrm{N}, \mathrm{P}$ & UK \\
\hline [54] & 2005 & Hanson et al. & Unknown & Constructed & $\mathrm{N}, \mathrm{P}$ & $\begin{array}{l}\text { Southern } \\
\text { Sweden }\end{array}$ \\
\hline$[55]$ & 1994 & Hanson et al. & nr Kingston & Riparian & $\mathrm{NO}_{3}$ & USA \\
\hline [56] & 1993 & Haycock and Burt & $\begin{array}{l}\text { R.Leach } \\
\text { floodplain }\end{array}$ & Floodplain & $\mathrm{NO}_{3}$ & UK \\
\hline
\end{tabular}


Table 1. Cont.

\begin{tabular}{|c|c|c|c|c|c|c|}
\hline Ref No. & Year & Author(s) & Wetland Name & Wetland Type & $\begin{array}{c}\text { Nutrient } \\
\text { Retention }\end{array}$ & Country \\
\hline [57] & 1994 & Hey et al. & $\begin{array}{c}\text { Des Plains River } \\
\text { Wetlands }\end{array}$ & Riparian & $\mathrm{NO}_{3}, \mathrm{P}$ & $\begin{array}{c}\text { Chicago Illinois, } \\
\text { USA }\end{array}$ \\
\hline [58] & 1994 & Jansson et al. & $\begin{array}{l}\text { River Raan } \\
\text { catchment }\end{array}$ & Stream & $\mathrm{N}$ & $\begin{array}{l}\text { Southern } \\
\text { Sweden }\end{array}$ \\
\hline$[59]$ & 1984 & Johnston et al. & nr White Clay Lake & Marsh/swamp & $\mathrm{N}, \mathrm{P}$ & USA \\
\hline$[60]$ & 1993 & Jordan et al. & $\begin{array}{l}\text { Chester River } \\
\text { Catchment }\end{array}$ & Floodplain & $\mathrm{NO}_{3}, \mathrm{TP}$ & USA \\
\hline [61] & 2003 & Jordan et al. & Kent Island & Marsh/swamp & TN, TP & USA \\
\hline$[15]$ & 1996 & Kadlec and Knight & Unknown & Constructed & $\mathrm{N}, \mathrm{P}$ & North America \\
\hline$[62]$ & 2014 & Kim et al. & Unknown & $\begin{array}{c}\text { Partially } \\
\text { saturated } \\
\text { vertical flow } \\
\text { wetland }\end{array}$ & $\mathrm{NO}_{3}, \mathrm{TKN}$ & France \\
\hline$[63]$ & 1994 & Leonardson et al. & Unknown & Constructed & $\mathrm{N}, \mathrm{NO}_{3}, \mathrm{NH}_{4}$ & Sweden \\
\hline$[64]$ & 1995 & Maltby et al. & $\begin{array}{l}\text { Floodplains in } \\
\text { Devon }\end{array}$ & Floodplain & $\mathrm{N}$ & UK \\
\hline [65] & 1997 & Mander et al. & $\begin{array}{l}\text { Poriji River } \\
\text { catchment }\end{array}$ & Riparian & $\mathrm{N}, \mathrm{P}$ & Estonia \\
\hline$[66]$ & 2019 & Nakase et al. & Unknown & $\begin{array}{c}\text { Partially } \\
\text { saturated } \\
\text { vertical flow } \\
\text { wetland }\end{array}$ & $\mathrm{NO}_{3}, \mathrm{TN}$ & Mexico \\
\hline [67] & 2000 & Newman et al. & Unknown & Constructed & $\mathrm{N}, \mathrm{TN}, \mathrm{P}$ & Connecticut \\
\hline [68] & 1994 & Patruno and Russel & Yamba wetland & Marsh/swamp & $\mathrm{N}, \mathrm{P}$ & Australia \\
\hline [69] & 1996 & Peterson and Teal & Unknown & Constructed & $\mathrm{N}$ & New England \\
\hline [70] & 1994 & $\begin{array}{l}\text { Phipps and } \\
\text { Grumpton }\end{array}$ & Unknown & Constructed & $\mathrm{N}, \mathrm{P}$ & USA \\
\hline [71] & 1998 & Prior & $\begin{array}{l}\text { R.Lambourn } \\
\text { floodplain }\end{array}$ & Floodplain & $\mathrm{N}, \mathrm{P}$ & UK \\
\hline [72] & 1995 & Raisin and Mitchell & $\begin{array}{l}\text { Humphrey's } \\
\text { wetland }\end{array}$ & Marsh/swamp & TPN & Australia \\
\hline [73] & 2017 & Saeed and Sun & Unknown & $\begin{array}{c}\text { Partially } \\
\text { saturated } \\
\text { vertical flow } \\
\text { wetland }\end{array}$ & $\mathrm{TN}$ & Bangladesh \\
\hline [74] & 2019 & Sandoval et al. & Unknown & $\begin{array}{c}\text { Partially } \\
\text { saturated } \\
\text { vertical flow } \\
\text { wetland }\end{array}$ & $\mathrm{NO}_{3}$ & Mexico \\
\hline [75] & 2000 & $\begin{array}{c}\text { Schipper and } \\
\text { Vojvodic' Vukovic }\end{array}$ & Unknown & Constructed & $\mathrm{NO}_{3}$ & New Zealand \\
\hline [76] & 1989 & $\begin{array}{l}\text { Schwer and } \\
\text { Clausen }\end{array}$ & nr Charlotte & Riparian & $\mathrm{TP}, \mathrm{TN}$ & USA \\
\hline [77] & 1986 & Verhoeven & Unknown & Peatmires/fens/ & $\mathrm{N}, \mathrm{P}$ & US and Europe \\
\hline
\end{tabular}




\section{Operation and Management of Wetlands for Efficient Nitrogen Attenuation}

To optimize the process of nitrogen removal, the most suitable viable factors that create maximum efficiency must be recognized. Many investigations have been made to decode species and morphology of microbes by conventional microbe cultivation techniques, along with biogenetical approaches to upgrade the process of nitrogen removal. The biogenetical techniques employing $16 \mathrm{~S}$ rDNA-based molecular techniques such as clone libraries, fluorescent in situ hybridization, PCR-denaturing gradient gel-electrophoresis, and terminal restriction fragment length polymorphisms are the most suitable for monitoring the dynamics and associations of microorganisms in wastewater treatment systems.

While managing constructed wetlands, the most common problems encountered by the operator include: clogging by sludge sediment accumulation, depletion of oxygen, destruction of wetland layers, and short-circuit flow, etc. To resolve these constraints, aeration devices are set up to supply oxygen, along with efficient media development, exceptional sludge-extracting apparatus, and a pre-flow circuit, setting up another pipeline at both inflow and outflow.

Wetland performance chiefly relies on the operation and maintenance of the wetland, its design, and the growth of the macrophytes. Better maintenance extends the lifetime of the constructed wetlands, whereas flow rate and water level are improved to affect the performance of treatment wetlands. The water level usually influences the diffusion of atmospheric oxygen, hydraulic residence time, and diversity of plants. During the summer season, the water level decreases to its lowest value, and as a result, the temperature of the water rises, which increases plant productivity, as well as oxygen diffusion rates. On the other hand, flow rates impact the hydraulic loading and contaminant loading, but can be managed by pretreatment.

Preserving the desired plant density is also a prime objective of operation and management, where a monoculture of plants successfully optimizes the nutrient removal rates, a diverse culture may create a "buffer" against changing local circumstances, which allows the vegetation community to acclimatize more readily. In a practical environment, wetlands collect different wastewater loadings, as well as irregular inputs of energy and moisture. Undesirable mixing of these inputs may result in constant rate estimation errors. Lately, many tracer examinations have been performed for treatment wetlands, while tracer techniques have occasionally been utilized in wetland data analysis. As a substitute, a constant-flow modification of the first-order model has been universally accepted in data analysis and in constructing wetland designs. It is therefore required to establish verification techniques for tracer-designed wetland systems.

\section{Role of Wetlands in Biodiversity Enhancement}

Wetlands are globally significant, as they support a high diversity of plants and animals, especially birds, and also serve as transitional zones between water and land, and guard against storm upsurges and excessive flooding. Therefore, wetland security has become a priority internationally and is advocated by international conventions, like the International Convention of Biological Diversity and the Ramsar Convention. Besides acting as sinks of carbon dioxide, lacustrine and riverine wetlands frequently support a spawning habitat and yield juvenile fish species to adjoining aquatic systems.

Wetlands cover a total of 6 to 8 percent of the land on earth, and accommodate the 20 to 40 percent of flora and fauna species that are dependent on wetland ecosystems to complete their life cycles. Wetland loss results in droughts, flooding, soil erosion, loss of agricultural productivity, and biodiversity reduction, while about 37 percent of mammals, 21 percent of birds, 20 percent of freshwater fishes, and almost one third of amphibians are lost [78]. Decline in wetlands will influence the related systems, as loss of nursery habitat could destroy fisheries, or wetland reduction on a flyway could disturb migration of waterfowl, threatening the fertility rate of birds and their ultimate survival. Wetlands are also rich in geographically dispersed genetic resources, which ensures the adaptation of individuals to altering ecological conditions, i.e., global warming, and maintenance of 
distinctiveness of animal and plant species. Thus, wetland reduction endangers genetic resources, which is particularly significant for the evolution of numerous species.

There has been an extensive argument in the ecological literature regarding the association of animal, microbe, and plant diversity and ecosystem functioning, since the 1990s [79]. In a grassland study, a directly proportional relationship between the number of plant species and ecosystem functions such as decomposition and primary production was indicated. In a broader pattern of ecosystem types, investigations have revealed that diversity of vegetation can establish circumstances for exceptionally disparate trophic food webs and decomposer communities, which provide important ecosystem services [80]. The existence of functional redundancy likewise protects the ecosystem from losing its viability under severe circumstances.

In wetlands, variations in topography and hydrology impact the colonization of dominant vegetation that appears in a particular zonation pattern in tidal situations or forms a complex mosaic pattern of plant communities across the gradient. Reed [81] listed about 6728 species in the US National List of plant species that occur in wetlands. The plant species richness in various wetlands and their flower, fruits, and seedlings establish a great variety of animal species. However, most of the plant biomass does not enter the food chain, for instance in mangrove swamps, 10 percent of leaves are grazed by snails and small insects, while 90 percent fall off as leaf litter into the water. In riverine and estuarine wetlands, the debris constituting dead leaves, flowers, and twigs accounts for 17 tons per hectare per year, which supports a great diversity of related invertebrates [82].

Wetlands also provide a breeding habit for diverse bird species. Bacon [83] reported about 104 species in the Black River Morass, Jamaica, which comprised about 49 forest birds, 36 waterfowl, 11 seabirds, 7 prey birds, and a kingfisher, whilst about 251 bird species were found in the Cache River Basin, Illinois, USA. Various wetlands serve as resting and sustaining sites for migratory fauna, such as shorebirds and waders, who profit from the diverse food species and enhance the biodiversity of these wetlands. In a regional case study, it was put forth that twenty-four thousand hectares of the Cache River Basin in North America supported nearly two hundred thousand Canada Geese (Branta canadensis), thirty-five thousand Snow Geese (Anser caerulescens), and twenty-six thousand ducks during the winter yearly [84].

Based on the latest insights, one would speculate that wetlands having greater biodiversity will operate better and would show greater primary production, as well as nutrient retention; however, very little knowledge is available to test the said hypothesis. In various field experiments, species diversity was associated with different ecosystem functions by establishing wetland mesocosms having more variable plant functional types than number of species. In a comparative analysis of four variable plant functional types, isolated or combined, three major activities were reported that included: denitrification, methane emission, and primary production [85]. It was stated that an increase in plant functional types had a decreasing effect on methane emission but denitrification and primary production were not affected.

In another investigation, in 18 real-scale wetland experiments, free-development wetlands were correlated with wetlands cultivated with three emergent and three submerged species. It was seen that after four years, the number of plant species in the uncultivated and submerged vegetation wetland had increased but remained substantially lower in emergent vegetation wetlands. Nonetheless, the nitrogen attenuation was considerably higher in the emergent vegetation wetlands than in the others. This research pointed out that the performance of ecosystems does not necessarily depend on greater species diversity, instead the species identity and their traits are more significant in nitrogen removal [86].

Moreover, the addition of nutrients results in a possible biodiversity loss due to the alterations in functioning. Species-rich environs have been demonstrated to be fairly nutrient-rich and disclosed to transitional levels of disruption [87]. Natural wetlands accommodating diverse plant species are frequently mesotrophic and susceptible to eutrophication. Thus, adding nutrients will induce a rise in primary production along with 
biodiversity loss, because the competing species will replace the vegetation easily. Hence, such species-rich wetlands are not recommended for retaining nutrients, as the enhancement of water quality will harm the wetland's biodiversity.

From the current literature on the subject, the critical loading values for Nitrogen and Phosphorus identified for mesotrophic wetlands and natural wetlands are $4.0 \mathrm{~g} \mathrm{~N} \mathrm{~m}^{-2} \mathrm{y}^{-1}$, $0.5 \mathrm{~g} \mathrm{P} \mathrm{m}^{-2} \mathrm{y}^{-1}$ and $50 \mathrm{~g} \mathrm{~N} \mathrm{~m}^{-2} \mathrm{y}^{-1}, 4.0 \mathrm{~g} \mathrm{P} \mathrm{m}^{-2} \mathrm{y}^{-1}$, respectively [88-90]. It should also be noted that to counter eutrophication effects, only one of these elements ought to be restricting the primary production in wetlands. Nitrogen to phosphorous ratios often vary from 10-20, which is similar to that in living matter. In the case of high nitrogen loading, i.e., $900 \mathrm{~g} \mathrm{~N} \mathrm{~m}^{-2} \mathrm{y}^{-1}$, severe eutrophication of the wetland can be countered, only if phosphorous loading is less than $4.0 \mathrm{~g} \mathrm{~N} \mathrm{~m}^{-2} \mathrm{y}^{-1}$ [91].

Wetland ecosystems may also function as traps for nutrients moving from land to fresh water, and eventually to marine ecosystems. According to Hansson et al. [54] a more complex shoreline, larger surface area, and shallow depth of a wetland system support a greater diversity of benthic invertebrates, birds, and macrophytes, and are highly likely to retain high nitrogen contents. On the other hand, a small and deep wetland is supposedly more proficient in retaining phosphorous but is less substantial in terms of biodiversity. In another investigation, the plant species richness and flood frequency among 16 wetlands sites on a coastal island in Southeast Alaska were correlated. The data obtained also followed the Michael Huston dynamic-equilibrium model of species diversity, and it was noted that species-rich locations had low to intermediate productivity levels and average flood frequencies, that but species-poor locations exhibited low productivity but above average flood frequencies [92].

In southern Sweden, 220 wetlands have been established for nutrient retention from water streaming down a tile drainage before entering the water channel. Among these, 36 constructed wetlands were monitored for macroinvertebrate diversity and nitrogen removal, which was about 10\% [93]. The investigation revealed that these five-year-old wetlands gathered a great number of species complementary to the "mature" ponds. It was evident from the high alpha diversity (i.e., thirty-two species, 70 percent of the beta component, which indicated a considerable difference in species composition between the 36 wetlands and gamma component (120 species), and indicating the richness of species in these wetlands) that the fauna colonized these wetlands at a much faster pace [94]. Therefore, the constructed wetlands absolutely strengthened the regional biodiversity.

In Western Europe, the deposition of atmospheric contaminants has driven a drastic change in the composition of wetland communities. The dominant peat-forming Sphagnum cuspidatum, which were once prevalent in ombrotrophic peat bogs, are now diminished, and followed by an elevated level of nitrogen deposition in tissues. In a case study, five Sphagnum species were transplanted from an uncontaminated area to a polluted area, which showed an absolute increase of nitrogen of about $5.3 \mathrm{mg} / \mathrm{g}$ in tissue in Sphagnum capillifolium and $17.7 \mathrm{mg} / \mathrm{g}$ in Sphagnum recurvum, which were above the standard level of $10 \mathrm{mg} / \mathrm{g}$ [95]. In Netherlands, the correlation between the biodiversity, biomass, and chemical features of soil was demonstrated in various fens and grassland communities. It was observed that species were rich in number at the wetlands where the standing biomass varied from 400 to $500 \mathrm{~g} \mathrm{~m}^{-2}$. The pervasiveness of certain species is linked with eutrophic environment at the higher end of the biomass scale, along with unfavorable growth conditions at the lower end.

In the fens of Great Britain, it was observed that species were densely populated, i.e., 12 per $0.25 \mathrm{~m}^{2}$, where standing crops were fewer than $1000 \mathrm{~g} \mathrm{~m}^{-2}$, and less populated, i.e., 3 per $0.25 \mathrm{~m}^{2}$, if standing crop exceeded $4000 \mathrm{~g} \mathrm{~m}^{-2}$ [96]. Deviations from this statement were observed in the sites where the accumulation of surface litter was reduced by mowing and harvesting of vegetation in wetlands. Research has been carried out to indicate the nitrogen control measures on community structure. However, it is a complicated phenomenon, as nitrogen eutrophication has many direct and indirect effects on species diversity. For instance, acidification caused by $\mathrm{SO}_{4}{ }^{2-}, \mathrm{NO}$, or $\mathrm{NH}_{4}{ }^{+}$deposition can 
reduce the feasible dissolved $\mathrm{CO}_{2}$ in water, leading to the eradication of submerged plant species. Deposition of $\mathrm{NO}_{3}{ }^{-}$and $\mathrm{SO}_{4}{ }^{2-}$ creates alkaline conditions, whereas nitrification of $\mathrm{NH}_{4}{ }^{+}$produces acidity. These biological conversions are mediated by algae, bacteria, and macrophytes and can substantially alter the nitrogen budgets and eventually transform the community structure of wetlands.

The relationship between the acidification, growth, and nitrogen supply of seven wetland plants was explored, and it was showed that all wetland species employed $\mathrm{NO}_{3}{ }^{-}$ and $\mathrm{NH}_{4}{ }^{+}$as a source of nitrogen, excluding Sphagnum flexuosum, as it did not incorporate $\mathrm{NO}_{3}{ }^{-}$. It was observed that in alkaline waters, $\mathrm{NO}_{3}{ }^{-}$was the predominant form of nutrition, i.e., 63 to 73 percent in plants, contrary to the acidic waters, where $\mathrm{NH}_{4}{ }^{+}$strongly influenced the nutrition by up to 85 to 90 percent. These species differed in their sites of uptake, mainly leaves or roots. In this area, however, the acidification resulting from high $\mathrm{NH}_{4}{ }^{+}$and $\mathrm{SO}_{4}{ }^{2-}$ deposition was inducing the development of acid tolerant nitrophilous species [97]. It has not been found yet whether these patterns would be applicable for other biota such as flora and waterfowl, but it is valid that wetland vegetation is also partly responsible for the richness of biodiversity and habitat in the agricultural landscape. In another wetland investigation, it was observed that waterfowl along with grassland birds exclusively utilized the riparian zones of Maryland, USA, for breeding and foraging [98].

Almost 14 percent of the listed endangered species, with an additional 284 species that are considered potentially threatened, in the United States chiefly inhabit wetland ecosystems. Numerous endangered species, for instance green pitcher plants, are established in infertile habitats like ombrotrophic bogs, however, these species will not prevail if exogenous nitrogen inputs surpass $2 \mathrm{~g} \mathrm{~N} \mathrm{~m}^{-2} \mathrm{yr}^{-1}$. Despite the species richness in wetland ecosystems, only a small number of plant species have been explored regarding the impacts of nitrogen loading. Elevated levels of nitrogen inputs may preferably boost the growth of some species, and as all species ought to respond variably, this may ultimately lead to species dominance and change in composition. Morris [99] stated that bogs are likely to be the most vulnerable to nitrogen deposition, as they sustain nutrients directly from precipitation. While, fens, marshes, swamps, and intertidal wetlands can also be sensitive to anthropogenic nitrogen expansion from deposition and agricultural runoff via surface waters.

In a recent investigation, it was observed that $\mathrm{N}$-induced change in biodiversity from $\mathrm{C}_{3}$ plant species to $\mathrm{C}_{4}$ plant species in a brackish marsh in Maryland transformed the wetland community response to $\mathrm{CO}_{2}$ [100]. It was inferred that nitrogen loading can significantly increase organic matter deposition and ultimately carbon loss from saline marsh soils, which could possibly lead to deterioration of marsh structure and make them highly susceptible to changing sea levels. Hence, restored wetlands are undeniably significant for biodiversity enhancement.

\section{Future Prospects}

Recently identified techniques, including Anammox and CANON, have substantial potential for enhanced nitrogen attenuation efficiency and treatment performance in aquatic systems, nevertheless, there is a need to explore these techniques in constructed wetlands. Research on the identification of the growth circumstances of Anammox bacteria and the determination of design parameters to promote the suitable conditions must also be executed. Moreover, very few reports have documented nutrient loading in the wetlands of tropical and sub-tropical areas, particularly South America. Only a few publications are available on bogs and fens, with most of them being available for floodplains, marshes, riparian zones, and swamps. It was noted that during autumn and winter when most of the wetland macrophytes shed litter, an increase in soluble nutrient species is expected, but they may not be deleterious for aquatic bodies because of the dilution of these soluble inputs caused by higher river flows during these seasons. The impacts of nitrogen loading on regional biodiversity have also not yet been evaluated. It is presumed that wetland may become loaded with leaching nutrients, while decreasing eutrophication of vicinal ecosys- 
tems. To enhance the treatment performance in constructed wetland systems, the dominant microorganisms and hydrophytes containing a gene of interest for nitrogen attenuation, and acquiring biogenetical processes via gene modification of microbial-planted systems, should be further investigated. Advancements in this field might improve nitrogen removal efficiency and reduce the limitations and short-comings of natural ecosystems. To further enhance nitrogen removal, kinetic analysis, established on a mass balance evaluation of elements of nitrogen transformation techniques existing within the wetland treatment cells, and utilizing the isotope tracking ${ }^{15} \mathrm{~N}$ method, will yield mechanistic guidance for nitrogen conversions and the development of layouts for better operation of a system. Moreover, investigations made to improve water quality will contribute expertise in nutrient removal techniques in constructed wetland systems.

Constructed wetlands are cost-effective and stable systems, but are prone to perform inadequately because of the disintegration of microbial assimilation at low temperatures. With the aim of upgrading constructed wetland elements and the elimination of emerging contaminants, the future trends for research should encompass radiation plant breeding and the integration of treatment techniques to improve wastewater treatment, even at lower temperatures. Siphon constructed wetlands are an unpowered oxygenation technology that depends on siphon activity to discern between varying anoxic and aerobic conditions in wetland systems, and has future prospects of being planted in rural localities. Moreover, organic carbon also limits the nitrogen attenuation in constructed wetlands; generally, the denitrification process is ceased due to an inadequate amount of organic carbon caused by excess dissolved oxygen. Hence, for optimal removal of total nitrogen, not only research on optimal levels of dissolved oxygen is necessary, but the optimum input of water and efficient usage of agricultural refuse as sources of organic carbon for denitrification must be scrutinized.

\section{Conclusions}

Generally, the conventional pathway for nitrification-denitrification plays a significant role in nitrogen attenuation in wetlands systems. However, the removal rate is extremely restricted by the paucity of organic carbon that is essential for both nitrifying and denitrifying bacteria. Therefore, for efficient nitrogen removal, certain variables, such as temperature and HRT, that promote the growth of microbes and relative macrophytes must be optimized. Wetland operations also increase the environmental risk of enhanced greenhouse gas emissions, especially in sandy or acidic soil areas, yet the water pacification benefit counterbalances the hazards expected from nitrous oxide emissions. Investigations from all across the globe have also demonstrated that, while wetlands keep the nitrogen and phosphorous loading in check, the nutrient inputs will not jeopardize the flora and fauna diversity in agricultural landscapes.

Author Contributions: Conceptualization, A.Y. and N.K.; validation, A.N., data curation, N.N., W.S., U.E., Z.Q., A.K.; writing—original draft preparation, A.Y.; writing—review and editing, N.K., A.Y.; visualization, M.A.; supervision, N.K. All authors have read and agreed to the published version of the manuscript.

Funding: This review received no external funding.

Data Availability Statement: The data presented in this review are available on request from the corresponding author.

Conflicts of Interest: The authors declare no conflict of interest.

\section{References}

1. UNICEF Water: Sanitation and Hygiene Annual Report; UNICEF: New York, NY, USA, 2008.

2. O'Geen, A.T.; Budd, R.; Gan, J.; Maynard, J.J.; Parikh, S.J.; Dahlgren, R.A. Mitigating nonpoint source pollution in agriculture with constructed and restored wetlands. Adv. Agron. 2010, 108, 1-76. [CrossRef] 
3. Howarth, R.W.; Billen, G.; Swaney, D.; Townsend, A.; Jaworski, N.; Lajtha, K.; Downing, J.A.; Elmgren, R.; Caraco, N.; Jordan, T.; et al. Regional nitrogen budgets and riverine inputs of $\mathrm{N}$ and $\mathrm{P}$ for the drainages to the North Atlantic Ocean: Natural and human influences. Biogeochemistry. 1996, 35, 75-139. [CrossRef]

4. Hägg, H.E. Nitrogen Land-Sea Fluxes in The Baltic Sea Catchment-Empirical Relationships and Budgets. Ph.D. Thesis, University of Stockholm, Stockholm, Sweden, 2010.

5. Encyclopedia of Soils in The Environment. In Nitrates; Powlson, D.S.; Addiscott, T.M.; Hillel, D. (Eds.) Elsevier: Amsterdam, The Netherlands, 2005; pp. 21-31. [CrossRef]

6. Meisinger, J.J.; Palmer, R.E.; Timlin, D.J. Effects of tillage practices on drainage and nitrate leaching from winter wheat in the Northern Atlantic Coastal-Plain USA. Soil Tillage Res. 2015, 151, 18-27. [CrossRef]

7. Richardson, C.J. Freshwater Wetlands: Transformers, Filters, or Sinks? In Freshwater Wetlands and Wildlife; Sharitz, R.R., Gibbons, J.W., Eds.; The Department of Energy (DOE) Office of Scientific and Technical Information: Oak Ridge, TN, USA, 1989; pp. 25-46.

8. Mitsch, W.J. Global Wetlands: Old World and New; Elsevier Science: Amsterdam, The Netherlands, 1994.

9. Acreman, M.C. Impact Assessment of Wetlands: Focus on Hydrological and Hydrogeological Issues. Phase 2 Report. Environment Agency, Bristol (W6-091) and Centre for Ecology and Hydrology, Wallingford (C01996); Environment Agency: Bristol, UK, 2004.

10. Cowardin, L.V.; Carter, F.C. Classification of Wetlands and Deep Water. Habitats of the United States; US Department of Interior, Fish and Wildlife Service: Washington, DC, USA, 1979.

11. United States Environmental Protection Agency. 2006. Available online: http:/ / www.epa.gov/wetlands (accessed on 28 April 2021).

12. Sundaravadivel, M.; Vigneswaran, S. Constructed Wetlands for Wastewater treatment. Crit. Rev. Env. Sci. Technol. 2001, 31, 351-409. [CrossRef]

13. National Wetland Policy of Nepal; Ministry of Forests and Soil Conservation, Singh Durbar: Kathmandu, Nepal, 2003.

14. Thorsell, J.; Levy, R.F.; Sigaty, T. A Global Overview of Wetland and Marine Protected Areas on The World Heritage List. In Natural Heritage Programme; IUCN: Gland, Switzerland, 1997.

15. Kadlec, R.H.; Knight, R.L. Treatment Wetlands; Lewis-CRC Press: Boca Raton, FL, USA, 1996.

16. EPA (U.S. Environmental Protection Agency). Better Assessment Science Integrating Point and Nonpoint Sources (BASINS), User's Manual, Version 3.0. EPA-823-H-01-001; Office of Water, U.S. Environmental Protection Agency: Washington, DC, USA, 2001.

17. Richey, J.E.; Melak, J.M.; Aufdenkampe, A.K.; Ballester, V.M.; Hess, L.L. Outgassing from Amazonian rivers and wetlands as a large tropical source of atmospheric $\mathrm{CO}_{2}$. Nature 2002, 416, 617-620. [CrossRef] [PubMed]

18. Torrens, A.; Molle, P.; Boutin, C.; Salgot, M. Impact of design and operation variables on the performance of vertical-flow constructed wetlands and intermittent sand filters treating pond effluent. Water Res. 2009, 43, 1851-1858. [CrossRef] [PubMed]

19. Wallace, S.; Jiggins, J.; Crolla, A.; Kinsley, C.; Bachanc, A.; Verkuijl, S. Highrate Ammonium Removal in Aerated Engineered Wetlands. In Proceedings of the 10th International Conference on Wetland Systems for Water Pollution Control, Lisbon, Portugal, 23-29 September 2006.

20. Tiedje, J.M. Ecology of Denitrification and Dissimilatory Nitrate Reduction to Ammonium. In Biology of Anaerobic Microorganisms; Zehnder, A.J.B., Ed.; John and Wiley \& Sons, Inc.: New York, NY, USA, 1988; pp. 179-244.

21. Woodward, K.B.; Fellows, C.S.; Conway, C.L.; Hunter, H.M. Nitrate removal, denitrification and nitrous oxide production in the riparian zone of an ephemeral stream. Soil Biol. Biochem. 2009, 41, 671-680. [CrossRef]

22. Lin, Y.F.; Jing, S.R.; Lee, D.Y.; Wang, T.W. Effect of macrophytes and external carbon sources on nitrate removal from groundwater in constructed wetlands. Environ. Pollut. 2002, 119, 413-420. [CrossRef]

23. Mayo, A.W.; Bigambo, T. Nitrogen transformation in horizontal subsurface flow constructed wetlands I: Model development. Phys. Chem. Earth Parts A B C 2005, 30, 658-667. [CrossRef]

24. Groffman, P.M.; Altabet, M.A.; Böhlke, J.K.; Butterbach-Bahl, K.; David, M.B.; Firestone, M.K.; Giblin, A.E.; Kana, T.M.; Nielsen, L.P.; Voytek, M.A. Methods for Measuring Denitrification: Diverse Approaches to a Difficult Problem. Ecol. Appl. 2006, 16, 2091-2122. [CrossRef]

25. Nelson, J.W.; Kadlec, J.A. A conceptual approach to relating habitat structure and macroinvertebrate production in freshwater wetlands. Trans. N. Amer. Wildl. Nat. Resourc. Conf. 1984, 49, 262-270.

26. Swanson, G.A.; Meyer, M.I. Impact of fluctuating water levels on the feeding ecology of breeding blue-winged teal. J. Wildl. Manag. 1977, 41, 426-433. [CrossRef]

27. Kramer, P.J.; Boyer, J.S. Water Relations of Plants and Soil; Academic Press: San Diego, CA, USA, 1995.

28. Moreno, C.; Farahbakhshadzad, N.; Morrison, G.M. Ammonia removal from oil refinery effluent in vertical upflow macrophyte column systems. Water Air Soil Pollut. 2002, 135, 237-247. [CrossRef]

29. Hume, N.P.; Fleming, M.S.; Horne, A.J. Denitrification potential and carbon quality of four aquatic plants in wetland microcosms. Soil Sci. Soc. Am. J. 2002, 66, 1706-1712. [CrossRef]

30. Westlake, J.; Kvêt, J.; Szczepanski, A. The Production Ecology of Wetlands; Cambridge university press: Cambridge, UK, 1998.

31. Hamilton, W.A. Biofilms: Microbial Interactions and Metabolic Activities. In Ecology of Microbial Communities; Fletcher, M., Gray, T.R.G., Jones, J.G., Eds.; Cambridge University Press: Cambridge, UK, 1987; pp. 361-385.

32. Eriksson, P.G.; Andersson, J.L. Potential nitrification and cation exchange on litter of emergent, freshwater macrophytes. Freshwater Biol. 1999, 42, 479-486. 
33. Reddy, K.R.; D'Angelo, E.M.; DeBusk, T.A. Oxygen transport through aquatic macrophytes: The role in wastewater treatment. J. Environ. Qual. 1989, 19, 261-267. [CrossRef]

34. Zhang, X.B.; Liu, P.; Yang, Y.S.; Chen, W.R. Phytoremediation of urban wastewater by model wetlands with ornamental hydrophytes. J. Environ. Sci. 2007, 19, 902-990. [CrossRef]

35. Zurita, F.; Anda, J.D.; Belmont, M.A. Performance of laboratory-scale wetlands planted with tropical ornamental plants to treat domestic wastewater. Water Qual. Res. 2006, 41, 410-417. [CrossRef]

36. Green, C.; Tunstall, S.; Garner, J.; Ketteridge, A.M. Benefit Transfer: Rivers and Coasts. Paper Prepared for The CEGB Meeting on Benefit Transfer, H.M. Treasury. Publication No. 231; Flood Hazard Research Centre, Middlesex University: London, UK, 1994.

37. Lahav, O.; Artzi, E.; Tarre, S.; Green, M. Ammonium removal using a novel unsaturated flow biological filter with passive aeration. Water Res. 2010, 35, 397-404. [CrossRef]

38. Sun, G.; Austin, D. Completely autotrophic nitrogen-removal over nitrite in lab-scale constructed wetlands: Evidence from a mass balance study. Chemosphere 2007, 68, 1120-1128. [CrossRef] [PubMed]

39. Huang, J.; Yan, C.; Liu, J.; Guan, W.; Singh, R.P.; Cao, C.; Xiao, J. Feasibility Study of Vertical Flow Constructed Wetland for Tertiary Treatment of Nanosilver Wastewater and Temporal-Spatial Distribution of Pollutants and Microbial Community. J. Environ. Manag. 2019, 245, 28-36. [CrossRef] [PubMed]

40. Wissing, F. Wasserreinigung mit Pflanzen; Verlag Eugen Ulmer: Stuttgart, Germany, 1995.

41. Hammer, D.A. Designing constructed wetlands systems to treat agricultural nonpoint source pollution. Ecol. Eng. 1992, 1, 49-82. [CrossRef]

42. Axler, R.; McCarthy, B.; Henneck, J. NERCC Individual Alternative Wastewater Treatment Systems: Pollutant Removal in 2003 and Long-Term Performance. Northeast Regional Correctional Center, St. Louis County, Duluth, Minnesota. NRRI Technical Report NRRI/TR2004/28. Natural Resources Research Institute University of Minnesota-Duluth. 5013 Miller Trunk Highway; Natural Resources Research Institute University of Minnesota-Duluth: Duluth, MN, USA, 2004.

43. Baker, C.J.; Maltby, E. Nitrate Removal by River Marginal Wetlands: Factors Affecting the Provision of a Suitable Denitrification Environment. In Hydrology and Hydrochemistry of British Wetlands; Hughes, J., Healthwaite, L., Eds.; Wiley: Chichester, UK, 1995; pp. 291-313.

44. Bridgham, S.D.; Updegraff, K.; Pastor, J. Carbon, nitrogen, and phosphorus mineralization in northern wetlands. Ecology 1998, 79, 1545-1561. [CrossRef]

45. Burt, T.P.; Matchett, L.S.; Haycock, N.E. Floodplain as Buffer Zones. In United Kingdom Floodplains; Westbury Publishing: Otley: West Yorlshire, UK, 1998.

46. Busse, L.R.; Gunkel, G. Riparian alder fens-source or sink for nutrients and dissolved organic carbon?-2 Major sources and sinks. Limnologica 2002, 32, 44-53. [CrossRef]

47. Chauvelon, P. A wetland managed for agriculture as an interface between the Rhone river and the Vaccares lagoon (Camargue, France): Transfers of water and nutrients. Hydrobiologia 1998, 373, 181-191. [CrossRef]

48. Cooper, P.F.; Findlater, B.C. Constructed Wetlands in Water Pollution Control; Pergamon Press: New York, NY, USA, 1990.

49. Daniels, R.B.; Gilliam, J.W. Sediment and chemical load reduction by grass and riparian filters. Soil Sci. Soc. Amer. J. 1996, 60, 1231-1238. [CrossRef]

50. Dorge, J. Modeling nitrogen transformations in freshwater wetlands. Estimating nitrogen retention and removal in natural wetlands in relation to their hydrology and nutrient loadings. Ecol. Model. 1994, 75-76, 409-420. [CrossRef]

51. Fleischer, S.; Joelsson, A.; Stibe, L. The Potential Role of Ponds as Buffer Zones. In Buffer Zones: Their Processes and Potential in Water Protection; Haycock, N.E., Burt, T.P., Goulding, K.W.T., Pinay, G., Eds.; Quest Environmental: Harpenden, UK, 1997.

52. Gersberg, R.M.; Elkins, B.V.; Goldman, C.R. Nitrogen removal in artificial wetlands. Water Res. 1983, 17, 1009-1014. [CrossRef]

53. Green, M.B.; Upton, J. Reed Bed Treatment for Small Communities-UK Experience. Ch. 57 in Constructed Wetlands for Water Quality Improvement; Moshiri, G.A., Ed.; CRC Press: Boca Raton, FL, USA, 1993.

54. Hansson, L.A.; Bronmark, C.; Nilsson, P.; Anders Abjornsson, K. Conflicting demands on wetland ecosystem services: Nutrient retention, biodiversity, or both? Freshw. Biol. 2005, 5, 705-714. [CrossRef]

55. Hanson, G.C.; Groffman, P.M.; Gold, A.J. Denitrification in riparian wetlands receiving high and low groundwater nitrate inputs. J. Environ. Qual. 1994, 23, 917-922. [CrossRef]

56. Haycock, N.E.; Burt, T.P. Role of floodplain sediments in reducing the nitrate concentration of subsurface run-off: A case study in the Cotswolds, UK. Hydrol. Process. 1993, 7, 287-295. [CrossRef]

57. Hey, D.L.; Kenimer, A.L.; Barrett, K.R. Water quality improvement by four experimental wetlands. Ecol. Eng. 1994, 3, 381-394. [CrossRef]

58. Jansson, M.; Andersson, R.; Berggren, H.; Leonardson, L. Wetlands and lakes as nitrogen traps. Ambio 1994, $23,320-325$.

59. Johnston, C.A.; Bubenzer, G.D.; Lee, G.B.; Madison, F.W.; McHenry, J.R. Nutrient trapping by sediment deposition in a seasonally flooded lakeside wetland. J. Environ. Qual. 1984, 13, 283-290. [CrossRef]

60. Jordan, T.E.; Correll, D.L.; Weller, D.E. Nutrient interception by a riparian forest receiving inputs from adjacent cropland. J. Environ. Qual. 1993, 22, 467-473. [CrossRef]

61. Jordan, T.E.; Whigham, D.F.; Hofmockel, K.H.; Pittek, M.A. Nutrient and sediment removal by a restored wetland receiving agricultural runoff. J. Environ. Qual. 2003, 32, 1534-1547. [CrossRef] 
62. Kim, B.; Gautier, M.; Prost-Boucle, S.; Molle, P.; Michel, P.; Gourdon, R. Performance evaluation of partially saturated vertical-flow constructed wetland with trickling filter and chemical precipitation for domestic and winery wastewaters treatment. Ecol. Eng. 2014, 71, 41-47. [CrossRef]

63. Leonardson, L.; Bengtsson, L.; Davidsson, T.; Persson, T.; Emanuelsson, U. Nitrogen retention in artificially flooded meadows Nitrogen retention in artificially flooded meadows. Ambio 1994, 23, 332-341.

64. Maltby, E.; Hogan, D.V.; Oliver, G.A. Wetland Soil Hydrological and Ecosystem Functioning. In Hydrology and Hydrochemistry of British Wetlands; Hughes, J.M.R., Heathwaite, A.L., Eds.; Wiley: Chicester, UK, 1995; pp. 325-362.

65. Mander, U.; Lomus, K.; Kuusemets, V.; Ivask, M. The Potential Role of Wet Meadows and Grey Alder Forests as Buffer Zones. In Buffer Zones: Their Processes and Potential in Water Protection; Haycock, N.E., Burt, T.P., Goulding, K.W.T., Pinay, G., Eds.; Quest Environmental: Harpenden, UK, 1997.

66. Nakase, C.; Zurita, F.; Nani, G.; Reyes, G.; Fernández-Lambert, G.; Cabrera-Hernández, A.; Sandoval, L. Nitrogen removal from domestic wastewater and the development of tropical ornamental plants in partially saturated mesocosm-scale constructed wetlands. Int. J. Environ. Res. Public Health 2019, 16, 4800. [CrossRef]

67. Newman, J.M.; Clausen, J.C.; Neafsey, J.A. Seasonal performance of a wetland constructed to process dairy milkhouse wastewater in Connecticut. Ecol. Eng. 2000, 14, 181-198. [CrossRef]

68. Paturno, J.; Russell, J. Natural wetland polishing effluent discharging to Wooloweyah Lagoon. Water Sci. Technol. 1994, 29, 185-192. [CrossRef]

69. Peterson, S.B.; Teal, J.M. The role of plants in ecologically engineered wastewater treatment systems. Ecol. Eng. 1996, 6, 137-148. [CrossRef]

70. Phipps, R.G.; Crumpton, W.G. Factors affecting nitrogen loss in experimental wetlands with different hydrologic loads. Ecol. Eng. 1994, 3, 399-408. [CrossRef]

71. Prior, H. Total Nitrogen and Total Phosphorous Cycling in Riparian Ecosystems. Ph.D. Thesis, University of Reading, Whiteknights, Reading, UK, 1998.

72. Raisin, G.W.; Mitchell, D.S. The use of wetlands for the control of non-point source pollution. Water Sci. Technol. 1995, 32, 177-186. [CrossRef]

73. Saeed, T.; Sun, G. Pollutant removals employing unsaturated and partially saturated vertical flow wetlands: A comparative study. Chem. Eng. J. 2017, 325, 332-341. [CrossRef]

74. Sandoval, L.; Marín-Muñiz, J.L.; Zamora-Castro, S.A.; Sandoval-Salas, F.; Alvarado-Lassman, A. Evaluation of wastewater treatment by microcosms of vertical subsurface wetlands in partially saturated conditions planted with ornamental plants and filled with mineral and plastic substrates. Int. J. Environ. Res. Public Health 2019, 16, 167. [CrossRef]

75. Schipper, L.A.; Vojvodic-Vukovic, M. Nitrate removal from groundwater and denitrification rates in a porous treatment wall amended with sawdust. Ecol. Eng. 2000, 14, 269-278. [CrossRef]

76. Schwer, C.B.; Clausen, J.C. Vegetation filter treatment of diary milk house wastewater. J. Environ. Qual. 1989, 18, 446-451. [CrossRef]

77. Verhoeven, J.T.A. Nutrient dynamics in minerotrophic peat mires. Aquat. Bot. 1986, 25, 117-167. [CrossRef]

78. Bang, W.H.; Jung, Y.; Park, J.W.; Lee, S.; Maeng, S.K. Effects of hydraulic loading rate and organic load on the performance of a pilot-scale hybrid VF-HF constructed wetland in treating secondary effluent. Chemosphere 2019, 218, 232-240. [CrossRef] [PubMed]

79. Loreau, M.; Naeem, S.; Inchausti, P.; Bengtsson, J.; Grime, J.P.; Hector, A.; Hooper, D.U.; Huston, M.A.; Raffaelli, D.; Schmid, B.; et al. Ecology—Biodiversity and ecosystem functioning: Current knowledge and future challenges. Science 2001, 294, 804-808. [CrossRef] [PubMed]

80. Isbell, F.; Calcagno, V.; Hector, A.; Connolly, J.; Harpole, W.S.; Reich, P.B.; SchererLorenzen, M.; Schmid, B.; Tilman, D.; van Ruijven, J.; et al. High plant diversity is needed to maintain ecosystem services. Nature 2011, 477, 199-202. [CrossRef] [PubMed]

81. Reed, P.B. National List of Plant Species That Occur in Wetlands: National summary. U.S. Fish Wildl. Serv. Biol. Rep. 1988, 88, 244.

82. Lugo, A.E.; Brinson, M.; Brown, S. Forested Wetlands. Ecosystems of the World; Elsevier Science: Amsterdam, The Netherlands, 1990; p. 15.

83. Bacon, P.R. Use of wetlands for tourism in the Insular Caribbean. Ann. Tour. Res. 1987, 14, 104-117. [CrossRef]

84. U.S. Fish \& Wildlife Service. A Joint Venture Proposal for Designation as Wetlands of International Importance: The Cache River and Cypress Creek Wetlands Area of South Illinois. Report of the U.S. Fish E Wildlife Service and Illinois Department of Conservation; U.S. Fish and Wildlife Service: Washington, DC, USA, 1994.

85. Bouchard, V.; Frey, S.D.; Gilbert, J.M.; Reed, S.E. Effects of macrophyte functional group richness on emergent freshwater wetland functions. Ecology 2007, 88, 2903-2914. [CrossRef]

86. Weisner, S.E.; Thiere, G. Effects of vegetation state on biodiversity and nitrogen retention in created wetlands: A test of the biodiversity-ecosystem functioning hypothesis. Freshw. Biol. 2010, 55, 387-396. [CrossRef]

87. Keddy, P. Putting the plants back into plant ecology: Six pragmatic models for understanding and conserving plant diversity. Ann. Bot. 2005, 96, 177-189. [CrossRef]

88. Ardon, M.; Montanari, S.; Morse, J.L.; Doyle, M.W.; Bernhardt, E.S. Phosphorus export from a restored wetland ecosystem in response to natural and experimental hydrologic fluctuations. J. Geophys. Res. Biogeosci. 2010, 115, G04031. [CrossRef] 
89. Moustafa, M.; White, J.; Coghlan, C.; Reddy, K. Influence of hydropattern and vegetation type on phosphorus dynamics in flow-through wetland treatment systems. Ecol. Eng. 2011, 37, 1369-1378. [CrossRef]

90. Walker, W.W.; Kadlec, R.H. Modeling phosphorus dynamics in Everglades wetlands and stormwater treatment areas. Crit. Rev. Environ. Sci. Technol. 2011, 41, 430-446. [CrossRef]

91. Bastviken, S.K.; Weisner, S.E.; Thiere, G.; Svensson, J.M.; Ehde, P.M.; Tonderski, K.S. Effects of vegetation and hydraulic load on seasonal nitrate removal in treatment wetlands. Ecol. Eng. 2009, 35, 946-952. [CrossRef]

92. Pollock, M.M.; Naiman, R.J.; Hanley, T.A. Plant species richness in riparian wetlands. A test of biodiversity theory. Ecol. 1998, 79, 94-105.

93. Thiere, G.; Milenkovski, S.; Lindgren, P.E.; Sahlen, G.; Berglund, O.; Weisner, S.E.B. Wetland creation in agricultural landscapes: Biodiversity benefits on local and regional scales. Biol. Conserv. 2009, 142, 964-973. [CrossRef]

94. Hey, D.L.; Cardamone, M.A.; Sather, J.H.; Mitsch, W.J. Restoration of Riverine Wetlands: The Des Plaines River Wetlands Demonstration Project; An Introduction to Ecotechnology; Mitsch, W.J., Jorgensen, S.E., Eds.; Ecological Engineering; John Wiley \& Sons: New York, NY, USA, 1989; pp. 159-183.

95. Ferguson, P.; Robinson, R.N.; Press, M.C.; Lee, J.A. Element concentrations in five Sphagnum species in relation to atmospheric pollution. Bryologist 1984, 13, 107-114.

96. Wheeler, B.D.; Giller, K.E. Species richness of herbaceous fen vegetation in Broadland, Norfolk in relation to the quantity of above-ground plant material. J. Ecol. 1982, 70, 179-200. [CrossRef]

97. Schuurkes, J.A.A.R.; Kok, C.J.; den Hartog, C. Ammonium ad nitrate uptake by aquatic plants from poorly buffered and acidified waters. Aquat. Bot. 1986, 24, 131-146.

98. Blank, P.J.; Dively, G.P.; Gill, D.E.; Rewa, C.A. Bird community response to filter strips in Maryland. J. Wildl. Manag. 2011, 75, 116-125. [CrossRef]

99. Morris, J.D. Effects of nitrogen loading on wetland ecosystems with particular reference to atmospheric deposition. Annu. Rev. Ecol. Syst. 1991, 22, 257-279. [CrossRef]

100. Langley, J.A.; Megonigal, J.P. Ecosystem response to elevated $\mathrm{CO}_{2}$ levels limited by nitrogen-induced plant species shift. Nature 2010, 466, 96-99. [CrossRef] [PubMed] 